\title{
Physical Properties of Ground Parboiled Fresh Rice Hulls Used as a Horticultural Root Substrate
}

\author{
Johann S. Buck ${ }^{1}$ and Michael R. Evans ${ }^{2,3}$ \\ University of Arkansas, Department of Horticulture, 315 Plant Sciences \\ Building, Fayetteville, AR 72701
}

Additional index words. total pore space, air-filled pore space, water-holding capacity, bulk density, particle density, water release curves

\begin{abstract}
Fresh parboiled rice hulls ground in a hammer mill and screened through a 1.18-mm screen and collected on a $0.18-\mathrm{mm}$ screen (RH3) and particles with a specific diameter of 0.5 to $1.0 \mathrm{~mm}$ had total pore space (TPS), air-filled pore space (AFP), and water-holding capacity (WHC) similar to that of Canadian sphagnum peat (peat). However, RH3 had more available water, a higher bulk density (BD), and a higher particle density (PD) than peat. When blended with $20 \%$ to $40 \%$ perlite or $1 \mathrm{~cm}$ aged pine bark, RH3-based substrates had lower TPS, similar AFP, and lower WHC than equivalent peat-based substrates. The RH3-containing substrates had higher BD and average $P D$ than equivalent peat-based substrates. When blended with parboiled rice hulls (PBH), RH3-based substrates had lower TPS than equivalent peat-based substrates. When blended with $20 \%$ to $40 \%$ PBH, RH3-based substrates had lower AFP than equivalent peat-based substrates. RH3-based substrates containing up to $20 \% \mathrm{PBH}$ had lower WHC than equivalent peat-based substrates. RH3-based substrates containing $40 \%$ PBH had a higher WHC than equivalent peat-based substrates. When blended with PBH, all RH3-based substrates had higher BD and average PD than equivalent peatbased substrates. The addition of $40 \% \mathrm{RH}$ to a peat-based substrate containing $20 \%$ perlite decreased substrate TPS, whereas the addition of $10 \%$ to $40 \%$ decreased AFP. The addition of $10 \%$ to $30 \% \mathrm{RH} 3$ increased WHC. The addition of $30 \% \mathrm{RH} 3$ to a peatbased substrate containing $20 \% 1 \mathrm{~cm}$ aged pine bark decreased substrate TPS and the addition of $20 \%$ to $40 \%$ RH3 decreased AFP. The addition of $10 \%$ RH3 increased WHC, but the addition of $20 \%$ or more RH3 did not affect WHC. The addition of $30 \%$ RH3 increased the BD, but the addition of RH3 had no effect on average PD. The addition of $20 \%$ or more and $30 \%$ or more RH3 to a peat-based substrate containing $20 \%$ PBH decreased substrate TPS and AFP, respectively. The addition $20 \% \mathrm{RH} 3$ decreased WHC. The addition of $10 \%$ to $40 \%$ RH3 increased BD. Overall, RH3 was the ground rice hull product that had physical properties most similar to peat. Peat-based substrates in which up to $40 \%$ of the peat was replaced with RH3 had physical properties that, although different from peat controls, were within commonly recommended ranges for substrates used to grow greenhouse crops.
\end{abstract}

Soilless root substrates (substrates) are commonly used in the production of containerized greenhouse and nursery crops (Bunt, 1988; Nelson, 2003). Substrates are formulated from various organic and inorganic components to provide suitable physical and chemical properties as required by the specific crop and cultural conditions (Bunt, 1988). One of the most common materials used in the formulation of substrates is sphagnum peat (peat). However, environmental concerns (Barkham, 1993; Buckland, 1993; Robertson, 1993) in the European Union and cost in markets such as Japan that are far from commercial sphagnum peat sources have generated significant interest

\footnotetext{
Received for publication 22 Dec. 2009. Accepted for publication 12 Feb. 2010.

${ }^{1}$ Former Graduate Student.

${ }^{2}$ Professor.

${ }^{3}$ To whom reprint requests should be addressed; e-mailjohann.buck@yahoo.com.
}

in the development of new substrate components that could serve as alternatives to peat used in substrates. Additionally, an increased emphasis on sustainability has increased interest in finding uses for agricultural and municipal byproducts and one of the potential areas in which such byproducts might be used is as horticultural substrate components.

Most research on the development of alternatives to peat in substrates has been focused on agricultural, industrial, and municipal waste products. Among these products were coconut coir (Evans and Stamps, 1996), cotton gin waste (Wang, 1991), waste paper products (Chong and Cline, 1993), composted rice hulls (Laiche and Nash, 1990), kenaf (Wang, 1994), composted yard waste (Beeson, 1996), ground feather fiber (Evans, 2004), ground pine tree wood (Jackson et al., 2008), and various composted animal manures (Tyler et al., 1993). Although some of these materials have been successfully used, some were not produced in large enough quantities to impact the market, some were too expensive for their intended use, some had a high degree of variability, and others had a high likelihood of containing contaminants such as metal fragments, glass, lead, and mercury.

Rice is produced in many areas of the world and in the United States extensively in Arkansas, California, Florida, Louisiana, Mississippi, Missouri, and Texas. Rice hulls are a byproduct of the rice milling industry and consist mainly of hemicellulose, lignin, and amorphous silica (Juliano et al., 1987). Kamath and Proctor (1998) estimated that 34 million tons of fresh rice hulls were produced annually in the United States. According to Bunt (1988) and Hanan (1998), fresh rice hulls had a bulk density of $0.10 \mathrm{~g} \cdot \mathrm{cm}^{-3}$, water-holding capacity of $20 \%(\mathrm{v} / \mathrm{v})$, total pore space of $89 \%(\mathrm{v} / \mathrm{v})$, and an air-filled pore space of $69 \%(\mathrm{v} / \mathrm{v})$. Evans and Gachukia (2007) demonstrated that the large particle size of whole parboiled fresh rice hulls increased drainage and air-filled pore space in peat-based substrates without causing significant nitrogen immobilization. Evans and Gachukia (2004) also reported that shoot and root dry weights of impatiens (Impatiens wallerianana Hook), marigold (Tagetes patula L.), and pansy (Viola $\times$ Wittrockiana Gams.) grown in perlite-containing substrates were not significantly different from those grown in parboiled fresh rice hullcontaining substrates.

Sambo et al. (2008) reported the physical properties of various ground nonparboiled fresh rice hulls. No fresh ground rice hulls products passed through 1-, 2-, 4-, or 6-mm diameter screens had the same physical properties as peat. All ground fresh rice hull products had higher bulk density, lower total pore space, higher air-filled pore space, and lower water-holding capacity than sphagnum peat.

In most situations, the physical properties of substrates are largely determined by the size of the particles of the substrate components. Larger particles tend to result in the creation of larger pores. Larger pores tend to drain after irrigation and provide the air-filled pore space of the substrate (Bunt, 1988; Raviv and Lieth, 2008). As the particle sizes increase or the proportion of large particles in the substrate increases, the air-filled pore space decreases. In contrast, smaller particles tend to pack more closely together than larger particles. Closer packing results in a decrease in air-filled pore space and may result in a decrease in total pore space, an increase in water-holding capacity, or both

Because substrate particle size influences pore size and pore size directly influences substrate physical properties, it should be possible to manipulate the physical properties of ground parboiled fresh rice hulls by altering the grind size and the sieve dimensions to produce a product with different particle sizes or different mixtures of particle sizes that have physical properties similar to sphagnum peat. Therefore, the objectives of this research were to develop a ground parboiled fresh rice hull product with physical properties similar to sphagnum peat and to 
evaluate how the inclusion of such a ground rice hull product as a complete or partial substitute for peat with different common aggregates affects the physical properties of the substrates.

\section{Materials and Methods}

Physical properties of ground parboiled fresh rice hull products. Whole parboiled fresh rice hulls $(\mathrm{PBH})$ were obtained from Riceland Foods, Inc. (Stuttgart, AR). Sphagnum peat was obtained from Sun Gro Horticulture (Bellevue, WA). Two ground rice hull products (RH1 and RH2) were produced by grinding $\mathrm{PBH}$ in a rotary Wiley mill (CSC Scientific, Inc., Fairfax, VA) using a diamondshaped screen with 5 -mm wide $\times 8$-mm high openings. The RH1 product was $\mathrm{PBH}$ that was processed once through the Wiley mill, whereas the $\mathrm{RH} 2$ product was processed twice through the Wiley mill using the same screen. A third ground rice hull product (RH3) was a commercially available, ground $\mathrm{PBH}$ material (Riceland Foods, Inc.) that was ground in a hammer mill until it passed through a screen with 1.18-mm diameter openings and was collected on a screen with $0.18-\mathrm{mm}$ openings. These three ground rice hull products were a mixture of particle sizes and are referred to as grades in this article.

The particle size distribution of each ground parboiled fresh rice hull grade and peat was determined by sieving dry $100-\mathrm{g}$ samples of each product for 2 min using a sieve shaker and a series of U.S. standard sieves with openings of 2.80, 2.00, 1.00, 0.50, and $0.25 \mathrm{~mm}$ (Fisher Scientific, Pittsburgh, PA). The amount of material collected on each screen was weighed, recorded, and calculated as a percentage $(\mathrm{w} / \mathrm{w})$ of the total sample.

An additional six ground rice hull products were produced by sieving the RH1 product to separate the particle fractions. The same sieve sizes described were used to separate the ground rice hull particles. This produced six ground rice hull products with discrete particle sizes of greater than $2.8 \mathrm{~mm}$ (P1), 2.0 to $2.8 \mathrm{~mm}(\mathrm{P} 2), 1.0$ to $2.0 \mathrm{~mm}$ (P3), 0.5 to $1.0 \mathrm{~mm}(\mathrm{P} 4), 0.25$ to $0.50 \mathrm{~mm}(\mathrm{P} 5)$, and less than $0.25 \mathrm{~mm}$ (P6).

For all of the ground rice hull products and peat, the total pore space (TPS; v/v), airfilled pore space (AFP; v/v), water-holding capacity (WHC; v/v), and bulk density (BD; $\mathrm{g} \cdot \mathrm{cm}^{-3}$ ) were determined using porometers according to methods described by Byrne and Carty (1989), Evans et al. (1996), and Fonteno and Bilderback (1993). The particle density $\left(\mathrm{PD} ; \mathrm{g} \cdot \mathrm{cm}^{-3}\right.$ ) was determined according to methods described by Niedziela and Nelson (1992). An analysis of variance (ANOVA) was conducted to determine if substrate physical properties differed significantly among the components. Single degree-offreedom contrasts of each rice hull product versus peat were conducted to determine significant differences in physical properties between each ground rice hull product and peat.
Water retention curves were developed by using a pressure plate system (Soil Moisture Equipment Corp., Santa Barbara, CA) according to methods described by Carter (1993). Peat and rice hull products were packed into brass cylinders that were $60 \mathrm{~mm}$ tall with a diameter of $54 \mathrm{~mm}$. The bottom openings of the cylinders were sealed with cheesecloth. Samples were subjected to head pressures of $0,1,10,30,50,100$, and $300 \mathrm{kPa}$ in a pressure plate system. In this test, the water released from 0 to $1 \mathrm{kPa}$ of pressure was considered to be the AFP space and the water held at a pressure of $1 \mathrm{kPa}$ was considered to be total WHC. Water released from 1 to $10 \mathrm{kPa}$ was considered to be available water (Bunt, 1988; De Boodt and Verdonck, 1972). Water released at pressures higher than $10 \mathrm{kPa}$ was considered unavailable water (Ingram et al., 1993). Samples were dried in an oven at $80^{\circ} \mathrm{C}$ until they reached a constant weight. The dry weight was then used to determine the amount of water held by the substrate at each pressure. For peat and rice hull products, three cylinders were tested with each cylinder serving as a replication. Water release curves were plotted as substrate water content (v/v) versus pressure. Curve fitting was done using GraphPad Prism 5 (GraphPad Software, Inc., La Jolla, CA).

Physical properties of peat and ground rice hull-based substrates with varying concentrations of aggregates. Substrates were composed of $60 \%, 70 \%, 80 \%, 90 \%$, and $100 \%$ RH3 or peat with the remainder of the volume being perlite, $\mathrm{PBH}$, or $1-\mathrm{cm}$ diameter screened aged pine bark. The substrate components were blended in a rotary mixer for $1 \mathrm{~min}$ at $50 \mathrm{rpm}$. The substrate TPS, AFP, WHC, BD, and PD were determined in containers using the tube method as described by Niedziela and Nelson (1992). The experimental design was a completely randomized design with 15 replications. An ANOVA was conducted to determine if the physical properties of the substrates were affected by substrate composition. Where significant differences occurred, single degree- of-freedom contrasts were conducted to determine significant differences between root substrates containing RH3 versus substrates containing equivalent amounts of peat.

Physical properties of root substrates containing ground parboiled fresh rice hulls as a partial replacement of peat. All substrates contained $20 \%$ perlite, $\mathrm{PBH}$, or $1 \mathrm{~cm}$ aged screened aged pine bark. The substrates were composed of $0 \%, 10 \%, 20 \%, 30 \%$, or $40 \%$ RH3 with the remainder of the substrate volume being peat. The substrate TPS, AFP, WHC, BD, and PD were determined in containers using the tube method as described by Niedziela and Nelson (1992). The experiment was a completely randomized design with 15 replications. An ANOVA was conducted to determine if the physical properties of the substrates were affected by substrate composition. Where significant differences occurred, single degree-of-freedom contrasts were conducted to determine whether significant differences occurred between root substrates containing RH3 versus substrates containing equivalent amounts of peat.

\section{Results and Discussion}

Physical properties of ground parboiled fresh rice hull products. Peat had the highest proportion of particles exceeding $2.80 \mathrm{~mm}$. RH1 was composed primarily of particles greater than $2.80 \mathrm{~mm}$ and $1.00 \mathrm{~mm}$ to $2.00 \mathrm{~mm}$ in diameter (Fig. 1). RH2 and RH3 were composed primarily of particles with diameters of $1.0 \mathrm{~mm}$ to $2.0 \mathrm{~mm}$. The primary difference between $\mathrm{RH} 2$ and $\mathrm{RH} 3$ was that RH3 had a higher proportion of particles with diameters of 0.5 to $1.0 \mathrm{~mm}$.

All of the ground rice hull products, whether a grade or specific particle size, had a higher BD and PD than peat (Tables 1 and 2). Generally, as the size of the rice hull particle decreased, the BD increased (Table 2 ). Peat had a significantly lower TPS than RH1 but a similar TPS as RH2 and RH3 (Table 1). Peat had a lower TPS than P1, P2, and $\mathrm{P} 3$ but a similar TPS as P4, P5, and P6

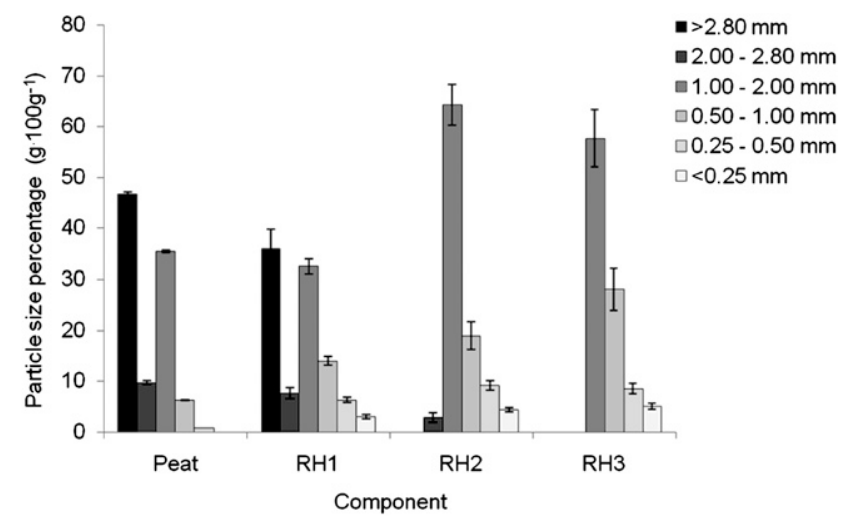

Fig. 1. Particle size distribution for sphagnum peat and three ground parboiled fresh rice hull products (RH1, RH2, and RH3). RH1 and RH2 were parboiled fresh rice hulls ground once and twice in a Wiley mill and passed through a $5-\mathrm{mm}$ wide $\times 8-\mathrm{mm}$ high screen, respectively. RH3 was a commercially available rice hull product ground using a hammer mill, passed through a $1.18-\mathrm{mm}$ screen, and collected on a $0.18-\mathrm{mm}$ screen (Riceland Foods, Stuttgart, AR). Error bars represent the SE of the means. 
Table 1. Physical properties of peat and ground parboiled fresh rice hull products containing a mixture of particle sizes.

\begin{tabular}{|c|c|c|c|c|c|c|c|c|}
\hline Component $^{\mathrm{z}}$ & & $\begin{array}{c}\text { Bulk } \\
\text { density } \\
\left(\mathrm{g} \cdot \mathrm{cm}^{-3}\right)\end{array}$ & $\begin{array}{l}\text { Particle } \\
\text { density } \\
\left(\mathrm{g} \cdot \mathrm{cm}^{-3}\right)\end{array}$ & $\begin{array}{c}\text { Total pore } \\
\text { space } \\
(\% \mathrm{v} / \mathrm{v})\end{array}$ & $\begin{array}{l}\text { Air-filled } \\
\text { pore space } \\
(\% \mathrm{v} / \mathrm{v})\end{array}$ & $\begin{array}{l}\text { Water-holding } \\
\text { capacity }(\% \mathrm{v} / \mathrm{v})\end{array}$ & $\begin{array}{c}\text { Available } \\
\text { water } \\
\left(\mathrm{cm}^{3} / 100 \mathrm{~cm}^{3}\right)^{y}\end{array}$ & $\begin{array}{c}\text { Percent } \\
\text { available water } \\
\left(\mathrm{cm}^{3} / 100 \mathrm{~cm}^{3}\right)^{x}\end{array}$ \\
\hline$\overline{\mathrm{RH} 1}$ & & 0.2 & 1.3 & 86.9 & 39.6 & 42.3 & 25.8 & 61.0 \\
\hline RH2 & & 0.3 & 1.3 & 78.8 & 21.8 & 57.0 & 30.2 & 53.0 \\
\hline RH3 & & 0.3 & 1.1 & 74.9 & 16.2 & 58.8 & 31.6 & 53.7 \\
\hline Peat & & 0.1 & 0.4 & 79.2 & 13.9 & 65.3 & 14.6 & 22.4 \\
\hline Significance & $\mathrm{df}$ & & & & & & & \\
\hline Component & 3 & $* *$ & $* * *$ & $*$ & $* * *$ & $* * *$ & $* * *$ & $* * *$ \\
\hline RH1 versus peat & 1 & $* *$ & $* * *$ & $*$ & $* * *$ & $* * *$ & $* * *$ & $* * *$ \\
\hline RH2 versus peat & 1 & $* * *$ & $* * *$ & NS & $*$ & NS & $* * *$ & $* * *$ \\
\hline RH3 versus peat & 1 & $* * *$ & $* * *$ & NS & NS & NS & $* * *$ & $* * *$ \\
\hline
\end{tabular}

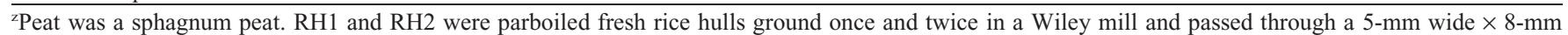

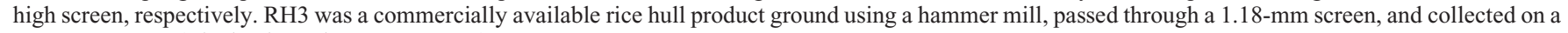
0.18-mm screen (Riceland Foods, Stuttgart, AR).

${ }^{\mathrm{y}}$ Available water was defined as water held at a pressure of 1 to $10 \mathrm{kPa}$.

xPercent water available defined as (available water/water-holding capacity) $\times 100$.

NS, $* * *, * * *$ Nonsignificant or significant at $P>\mathrm{F}=0.05,0.01$, or 0.001 , respectively.

Table 2. Physical properties of peat and different particle sizes of ground parboiled fresh rice hulls.

\begin{tabular}{|c|c|c|c|c|c|c|c|c|}
\hline Component $^{\mathrm{z}}$ & & $\begin{array}{c}\text { Bulk } \\
\text { density } \\
\left(\mathrm{g} \cdot \mathrm{cm}^{-3}\right)\end{array}$ & $\begin{array}{l}\text { Particle } \\
\text { density } \\
\left(\mathrm{g} \cdot \mathrm{cm}^{-3}\right)\end{array}$ & $\begin{array}{c}\text { Total pore } \\
\text { space } \\
(\% \mathrm{v} / \mathrm{v})\end{array}$ & $\begin{array}{c}\text { Air-filled } \\
\text { pore space } \\
(\% \mathrm{~V} / \mathrm{v})\end{array}$ & $\begin{array}{c}\text { Water-holding } \\
\text { capacity } \\
(\% \mathrm{v} / \mathrm{v})\end{array}$ & $\begin{array}{c}\text { Available } \\
\text { water } \\
\left(\mathrm{cm}^{3} / 100 \mathrm{~cm}^{3}\right)^{y}\end{array}$ & $\begin{array}{c}\text { Percent } \\
\text { available water } \\
\left(\mathrm{cm}^{3} / 100 \mathrm{~cm}^{3}\right)^{x}\end{array}$ \\
\hline$>2.80 \mathrm{~mm}(\mathrm{P} 1)$ & & 0.18 & 1.2 & 84.9 & 33.5 & 51.4 & 21.3 & 41.5 \\
\hline $2.00-2.80 \mathrm{~mm}(\mathrm{P} 2)$ & & 0.14 & 1.4 & 89.5 & 44.4 & 45.1 & 34.5 & 76.5 \\
\hline $1.00-2.00 \mathrm{~mm}(\mathrm{P} 3)$ & & 0.19 & 1.4 & 86.3 & 32.2 & 54.2 & 39.0 & 71.9 \\
\hline $0.50-1.00 \mathrm{~mm}(\mathrm{P} 4)$ & & 0.30 & 1.3 & 76.2 & 14.6 & 61.6 & 37.2 & 60.3 \\
\hline $0.25-0.50 \mathrm{~mm}(\mathrm{P} 5)$ & & 0.31 & 1.3 & 76.6 & 5.7 & 70.9 & 40.6 & 57.3 \\
\hline$<0.25 \mathrm{~mm}(\mathrm{P} 6)$ & & 0.33 & 1.3 & 73.9 & 4.0 & 69.9 & 6.0 & 8.5 \\
\hline Peat & & 0.09 & 0.4 & 79.2 & 13.9 & 65.3 & 17.0 & 24.0 \\
\hline Significance & $\mathrm{df}$ & & & & & & & \\
\hline Components & 6 & $* *$ & $* * *$ & $* *$ & $* * *$ & $* * *$ & $* * *$ & $* * *$ \\
\hline$P 1$ versus peat & 1 & $* * *$ & $* * *$ & * & $* * *$ & $* * *$ & $* * *$ & $* * *$ \\
\hline $\mathrm{P} 2$ versus peat & 1 & $*$ & $* * *$ & $* * *$ & $* * *$ & $* * *$ & $* * *$ & $* * *$ \\
\hline P3 versus peat & 1 & $* * *$ & $* * *$ & $* *$ & $* * *$ & $* *$ & $* * *$ & $* * *$ \\
\hline $\mathrm{P} 4$ versus peat & 1 & $* * *$ & $* * *$ & NS & NS & NS & $* * *$ & $* * *$ \\
\hline P5 versus peat & 1 & $* * *$ & $* * *$ & NS & $*$ & NS & $* * *$ & $* * *$ \\
\hline P6 versus peat & 1 & $* * *$ & $* * *$ & NS & $* *$ & NS & $* * *$ & $* * *$ \\
\hline
\end{tabular}

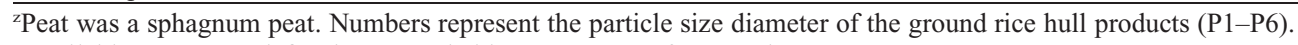

${ }^{y}$ Available water was defined as water held at a pressure of 1 to $10 \mathrm{kPa}$.

xPercent water available defined as (available water/water-holding capacity) $\times 100$.

NS, *,**, ***Nonsignificant or significant at $P>\mathrm{F}=0.05,0.01$, or 0.001 , respectively.

(Table 2). Peat had a lower AFP than RH1 and RH2 but a similar AFP as RH3. Peat had a lower AFP than P1, P2, and P3 but a higher AFP than P5 and P6. Peat had a similar AFP as P4. Peat had a higher WHC than RH1 but a similar WHC to RH2 and RH3. Peat had a higher WHC than P1, P2, and P3 but a similar WHC as P4, P5, and P6.

The model that best predicted the effect of increasing pressure on the water content was a one-phase decay model in which $\mathrm{y}=(\mathrm{Y} 0-$ plateau $)^{\left(-\mathrm{K}^{*} \mathrm{X}\right)}+$ plateau in which y was water content $\left(\mathrm{cm}^{3} / 100 \mathrm{~cm}^{3}\right)$; X was pressure $(\mathrm{kPa})$; $\mathrm{Y} 0$ was the $\mathrm{Y}$ value when $\mathrm{X}$ is zero expressed in the same units as $\mathrm{Y}$; plateau was the $\mathrm{Y}$ value at infinite times expressed in the same units as $\mathrm{Y}$; and $\mathrm{K}$ was the rate constant expressed in reciprocal of the $\mathrm{X}$ axis units. Except for P6, all rice hull products released more water at lower pressures than peat (Figs. 2 and 3) and thus had higher available water content and a higher percent of available water than peat (Tables 1 and 2). The P6 particle size released less water at pressures up to $10 \mathrm{kPa}$ and thus had less available water than peat.

The physical properties of the ground rice hulls can be at least partially explained as

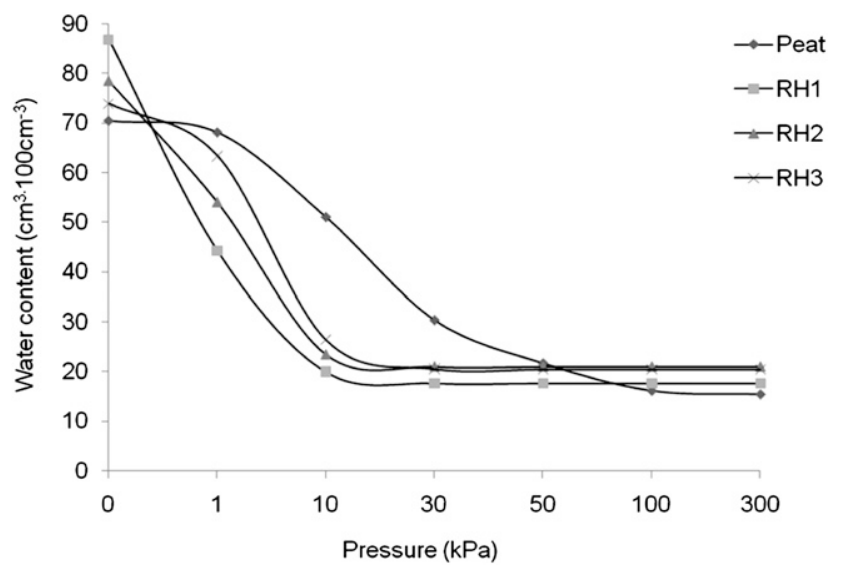

Fig. 2. Water release curves for sphagnum peat and various ground parboiled fresh rice hull products. Peat was a Canadian sphagnum peat. RH1 and RH2 were parboiled fresh rice hulls ground once and twice in a Wiley mill and passed through a $5-\mathrm{m}$ wide $\times 8-\mathrm{mm}$ high screen, respectively. RH3 was a commercially available rice hull product ground using a hammer mill, passed through a 1.18-mm screen, and collected on a $0.18-\mathrm{mm}$ screen. Regression equations for each material were: peat, $\mathrm{y}=(70.51-$ $15.5)^{(-0.0437 \mathrm{x})}+15.5, R^{2}=0.93 ; \mathrm{RH} 1, \mathrm{y}=(86.9-17.71)^{(-0.9564 \mathrm{x})}+17.71, R^{2}=0.98 ; \mathrm{RH} 2, \mathrm{y}=(78.6-$ $21.04)^{(-0.5537 \mathrm{x})}+21.04, R^{2}=0.97 ; \mathrm{RH} 3, \mathrm{y}=(73.96-20.5)^{(-0.2196 \mathrm{x})}+15.01, R^{2}=0.97$.

a function of particle size and PD. In most root substrates, as the particle size decreases, particles are able to pack more closely together, which reduces the larger sized pores and typically increases solids and BD and reduces AFP (Bunt, 1988; Nelson, 2003; 
Raviv and Lieth, 2008). As the particle size of the ground rice hulls decreased, or as the proportion of smaller particles increased in the ground rice hull grades, TPS and AFP decreased and WHC and BD increased. Rice hulls contained up to $20 \%$ silica (Juliano et al., 1987; Kamath and Proctor, 1998), whereas sphagnum peat was typically $96 \%$ organic matter with only traces of silica. This difference in composition would have contributed to ground rice hulls having a higher PD than peat. The higher particle density would in turn have increased the BD of all ground rice hull products as compared with peat.

The RH1 ground rice hull product had a higher percentage of particles with a diameter greater than $2.8 \mathrm{~mm}$ than $\mathrm{RH} 2$ and RH3, and RH2 and RH3 had a higher percentage of particles with a diameter of 0.5 to $2.0 \mathrm{~mm}$ than RH1. The lower percentage of large particles and the higher percentage of smaller particles resulted in RH1 having a higher TPS and AFP and a lower WHC than RH2 and RH3. Interestingly, the 0.5 to 1.0 (P4) particle size had physical properties most similar to those of peat and the RH3 material, which also had the properties most similar to peat and had the highest percentage of particles in the $0.5-$ to $1.0-\mathrm{mm}$ diameter. Pine tree substrates recommended by Jackson et al. (2008) were comprised primarily of particles 0.5 to $2.0 \mathrm{~mm}$ in diameter, which is larger than the optimal particle size for ground rice hulls. However, the TPS and the AFP of the pine tree substrates were higher than those of peat and the peat-based control substrates.

The differences in water release and available water could also be explained as a function of particle size. As the rice hull particle size decreased, or the proportion of smaller particles in the grade was increased, the proportion of very small pores that hold water more tightly would increase. This would in turn result in water being held at higher tensions, less water released at low pressures, and less available water. The P6 particle that had the smallest particle size had the lowest amount of available water and was the only rice hull product to have less available water than peat. Sambo et al. (2008) also reported that various ground rice hull products had a higher percent of available water than peat. Although available water was defined as the water that was released by a substrate at pressures up to $10 \mathrm{kPa}$ (Ingram et al., 1993), there is no agreement on the exact tension at which water is unavailable to plants in a soilless root substrate nor are there well-developed recommendations (Buamscha et al., 2007).

According to Yeager et al. (2007), the recommended $\mathrm{BD}$ of containerized crop root substrates was 0.19 to $0.70 \mathrm{~g} \cdot \mathrm{cm}^{-3}$. The optimal range for TPS in root substrates was $60 \%$ to $85 \%$ (Arnold Bik, 1983; Boertje, 1984; Jenkins and Jarrell, 1989), and Bunt (1988) and Jenkins and Jarrell (1989) both recommended an APS of $10 \%$ to $20 \%$. The optimal WHC has been reported to be between 45\% (Arnold Bik, 1983; Boertje, 1984) and $65 \%$ by volume (Jenkins and Jarrell, 1989). Therefore, RH3 and P4 had similar TPS, APS, and WHC compared with peat and although $\mathrm{BD}$ and $\mathrm{PD}$ were different from peat, all physical properties of RH3 and P6 were within recommended ranges. Because RH3 was the simplest product to manufacture, was a readily available commercial product, and had properties most similar to peat, it was selected as the ground rice hull product to be used in subsequent substrate evaluations.

Physical properties of peat and ground rice hull-based substrates with varying concentrations of aggregates. Regardless of the perlite concentration, peat-based substrates had lower BD and PD than equivalent RH3-based substrates (Table 3). At all perlite concentrations, peat-based substrates had a higher TPS than equivalent RH3-based substrates, but AFP was not different between peat-based substrates and RH-based substrates containing the same concentration of perlite. Peat-based substrates containing $0 \%$ to $30 \%$ perlite had higher WHC than equivalent RH3-based substrates. However, peatbased substrates containing $40 \%$ perlite had similar WHC as the equivalent RH3-based substrate.

At all bark concentrations, peat-based substrates had lower BD and PD than equivalent RH3-based substrates (Table 4). At all bark concentrations, peat-based substrates had a higher TPS than equivalent RH3-based substrates, but AFP was not different between peat-based substrates and RH-based substrates containing the same concentration of bark. Peat-based substrates containing $0 \%$, $10 \%, 30 \%$, and $40 \%$ bark had higher WHC than equivalent RH3-based substrates. However, peat-based substrates containing $20 \%$

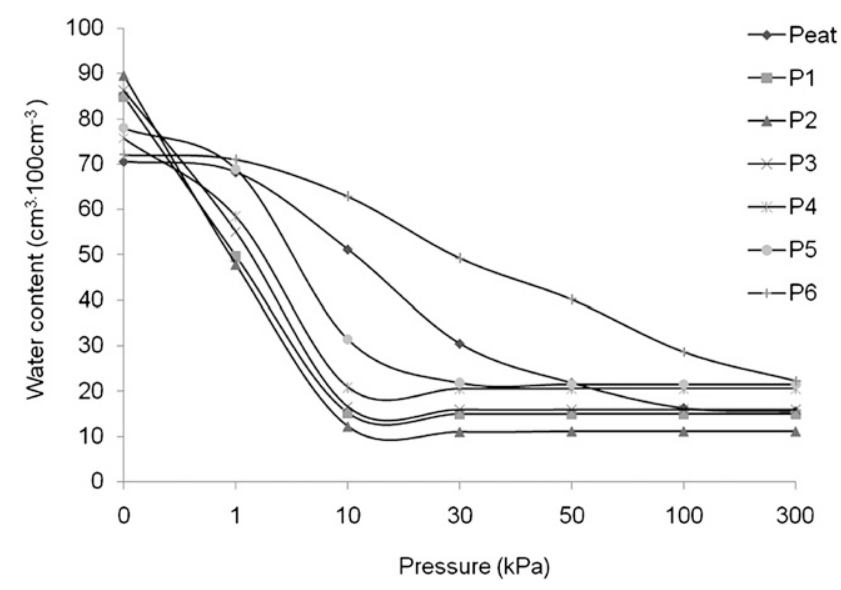

Fig. 3. Water release curves for sphagnum peat and various ground parboiled fresh rice hull particle sizes. Ground rice hull products P1, P2, P3, P4, P5, and P6 had particle sizes with a diameter greater than $2.80,2.0,1.0,0.5,0.25$, and less than $0.25 \mathrm{~mm}$, respectively. Regression equations for each material were: peat, $\mathrm{y}=(70.51-15.5)^{(-0.0437 \mathrm{x})}+15.5, R^{2}=0.93 ; \mathrm{P} 1, \mathrm{y}=(84.87-15.01)^{(-0.7013 \mathrm{x})}+15.01, R^{2}=0.97$ $\mathrm{P} 2, \mathrm{y}=(89.49-11.15)^{(-0.7598 \mathrm{x})}+11.15, R^{2}=0.99 ; \mathrm{P} 3, \mathrm{y}=(86.23-15.9)^{(-0.5857 \mathrm{x})}+15.9, R^{2}=0.99 ; \mathrm{P} 4$ $\mathrm{y}=(75.65-20.54)^{(-0.3757 \mathrm{x})}+20.54, R^{2}=0.94 ; \mathrm{P} 5, \mathrm{y}=(77.95-21.54)^{(-0.1745 \mathrm{x})}+21.54, R^{2}=0.99 ; \mathrm{P} 6$ $\mathrm{y}=(72.06-22.13)^{(-0.02039 \mathrm{x})}+22.13, R^{2}=0.94$.

Table 3. Physical properties of substrates comprised of sphagnum peat or ground parboiled fresh rice hulls amended with perlite.

\begin{tabular}{|c|c|c|c|c|c|c|}
\hline Substrate composition $^{z}$ & & $\begin{array}{c}\text { Bulk } \\
\text { density } \\
\left(\mathrm{g} \cdot \mathrm{cm}^{-3}\right)\end{array}$ & $\begin{array}{c}\text { Avg particle } \\
\text { density } \\
\left(\mathrm{g} \cdot \mathrm{cm}^{-3}\right)\end{array}$ & $\begin{array}{c}\text { Total pore } \\
\text { space } \\
(\% \mathrm{v} / \mathrm{v})\end{array}$ & $\begin{array}{c}\text { Air-filled } \\
\text { pore space } \\
(\% \mathrm{v} / \mathrm{v})\end{array}$ & $\begin{array}{c}\text { Water-holding } \\
\text { capacity } \\
(\% \mathrm{v} / \mathrm{v})\end{array}$ \\
\hline $100 \%$ peat: $0 \%$ perlite & & 0.09 & 0.38 & 71.1 & 12.8 & 58.3 \\
\hline $90 \%$ peat: $10 \%$ perlite & & 0.09 & 0.41 & 71.0 & 13.5 & 57.6 \\
\hline $80 \%$ peat: $20 \%$ perlite & & 0.10 & 0.40 & 69.3 & 13.6 & 55.7 \\
\hline $70 \%$ peat: $30 \%$ perlite & & 0.10 & 0.44 & 70.6 & 16.2 & 54.5 \\
\hline $60 \%$ peat: $40 \%$ perlite & & 0.10 & 0.41 & 69.5 & 17.0 & 52.5 \\
\hline 100\% RH3:0\% perlite & & 0.20 & 0.74 & 66.4 & 12.8 & 53.6 \\
\hline $90 \%$ RH3: $10 \%$ perlite & & 0.20 & 0.68 & 65.4 & 12.3 & 53.1 \\
\hline $80 \%$ RH3:20\% perlite & & 0.19 & 0.65 & 64.6 & 13.6 & 51.0 \\
\hline $70 \%$ RH3:30\% perlite & & 0.19 & 0.62 & 63.4 & 13.7 & 49.7 \\
\hline $60 \%$ RH $3: 40 \%$ perlite & & 0.19 & 0.65 & 65.3 & 14.0 & 51.3 \\
\hline Significance & $\mathrm{df}$ & & & & & \\
\hline Peat versus $\mathrm{RH} 3$ & 1 & $* * *$ & $* * *$ & $* * *$ & NS & $* * *$ \\
\hline $100 \%$ peat versus $100 \%$ RH3 & 1 & $* * *$ & $* * *$ & $* *$ & NS & $*$ \\
\hline $90 \%$ peat versus $90 \%$ RH3 & 1 & $* * *$ & $* * *$ & $* * *$ & NS & $*$ \\
\hline $80 \%$ peat versus $80 \% \mathrm{RH} 3$ & 1 & $* * *$ & $* * *$ & $* *$ & NS & $*$ \\
\hline $70 \%$ peat versus $70 \% \mathrm{RH} 3$ & 1 & $* * *$ & $* * *$ & $* * *$ & NS & $*$ \\
\hline $60 \%$ peat versus $60 \%$ RH3 & 1 & $* * *$ & $* * *$ & $*$ & NS & NS \\
\hline
\end{tabular}

${ }^{\mathrm{z}}$ Substrate composition indicates percentage sphagnum peat (peat), ground parboiled fresh rice hulls (RH3), and perlite.

$\mathrm{NS}, *, * *, * * *$ Nonsignificant or significant at $P>\mathrm{F}=0.05,0.01$, or 0.001 , respectively. 
bark had similar WHC as the equivalent RH3-based substrate.

Regardless of the $\mathrm{PBH}$ concentration, peat-based substrates had lower BD and PD than equivalent RH3-based substrates (Table 5). At all $\mathrm{PBH}$ concentrations, peat-based substrates had higher TPS than equivalent RH3-based substrates. Peat-based substrates containing 20\%, 30\%, and 40\% $\mathrm{PBH}$ had higher AFP than equivalent RH3-based substrates, but peat-based substrates containing $0 \%$ and $10 \%$ PBH had similar AFP as equivalent RH3-based substrates. Peat-based substrates containing $0 \%, 10 \%$, and $20 \% \mathrm{PBH}$ had higher WHC than equivalent RH3-based substrates. However, peat-based substrates containing $40 \% \mathrm{PBH}$ had lower WHC than RH3-based substrates with $40 \%$ PBH. Peat and RH3-based substrates containing 30\% PBH had similar WHC.

Table 4. Physical properties of substrates comprised of sphagnum peat or ground parboiled fresh rice hulls amended with $1 \mathrm{~cm}$ aged pine bark.

\begin{tabular}{|c|c|c|c|c|c|c|}
\hline Substrate composition ${ }^{z}$ & & $\begin{array}{c}\text { Bulk } \\
\text { density } \\
\left(\mathrm{g} \cdot \mathrm{cm}^{-3}\right)\end{array}$ & $\begin{array}{c}\text { Avg particle } \\
\text { density } \\
\left(\mathrm{g} \cdot \mathrm{cm}^{-3}\right)\end{array}$ & $\begin{array}{c}\text { Total pore } \\
\text { space } \\
(\% \mathrm{v} / \mathrm{v})\end{array}$ & $\begin{array}{c}\text { Air-filled } \\
\text { pore space } \\
(\% \mathrm{~V} / \mathrm{v})\end{array}$ & $\begin{array}{c}\text { Water-holding } \\
\text { capacity } \\
(\% \mathrm{v} / \mathrm{v})\end{array}$ \\
\hline $100 \%$ peat: $0 \%$ bark & & 0.09 & 0.37 & 70.9 & 12.6 & 58.4 \\
\hline $90 \%$ peat: $10 \%$ bark & & 0.10 & 0.41 & 70.5 & 11.4 & 59.1 \\
\hline $80 \%$ peat: $20 \%$ bark & & 0.11 & 0.48 & 71.2 & 13.4 & 57.8 \\
\hline $70 \%$ peat: $30 \%$ bark & & 0.11 & 0.50 & 71.0 & 12.7 & 58.2 \\
\hline $60 \%$ peat: $40 \%$ bark & & 0.10 & 0.44 & 69.0 & 12.2 & 56.8 \\
\hline $100 \%$ RH3:0\% bark & & 0.20 & 0.69 & 64.6 & 12.2 & 52.4 \\
\hline $90 \%$ RH3:10\% bark & & 0.21 & 0.77 & 66.8 & 12.5 & 54.4 \\
\hline $80 \%$ RH $3: 20 \%$ bark & & 0.20 & 0.83 & 67.9 & 11.8 & 56.1 \\
\hline $70 \%$ RH3:30\% bark & & 0.20 & 0.74 & 67.4 & 13.7 & 53.8 \\
\hline $60 \%$ RH3:40\% bark & & 0.20 & 0.70 & 65.9 & 13.1 & 52.8 \\
\hline Significance & $\mathrm{df}$ & & & & & \\
\hline Peat versus RH3 & 1 & $* * *$ & $* * *$ & $* * *$ & NS & $* * *$ \\
\hline $100 \%$ peat versus $100 \%$ RH3 & 1 & $* * *$ & $* * *$ & $* * *$ & NS & $* *$ \\
\hline $90 \%$ peat versus $90 \%$ RH3 & 1 & $* * *$ & $* * *$ & $*$ & NS & $*$ \\
\hline $80 \%$ peat versus $80 \%$ RH3 & 1 & $* * *$ & $* * *$ & $*$ & NS & NS \\
\hline $70 \%$ peat versus $70 \%$ RH3 & 1 & $* * *$ & $* * *$ & $*$ & NS & $*$ \\
\hline $60 \%$ peat versus $60 \%$ RH3 & 1 & $* * *$ & $* * *$ & $*$ & NS & $*$ \\
\hline
\end{tabular}

${ }^{\mathrm{z}}$ Substrate composition indicates percentage sphagnum peat (peat), ground parboiled fresh rice hulls (RH3), and perlite.

NS, *,**,***Nonsignificant or significant at $P>\mathrm{F}=0.05,0.01$, or 0.001 , respectively.

Table 5. Physical properties of substrates comprised of sphagnum peat or ground parboiled fresh rice hulls amended with PBH.

\begin{tabular}{|c|c|c|c|c|c|c|}
\hline Substrate composition ${ }^{2}$ & & $\begin{array}{c}\text { Bulk } \\
\text { density } \\
\left(\mathrm{g} \cdot \mathrm{cm}^{-3}\right)\end{array}$ & $\begin{array}{l}\text { Avg particle } \\
\text { density } \\
\left(\mathrm{g} \cdot \mathrm{cm}^{-3}\right)\end{array}$ & $\begin{array}{c}\text { Total pore } \\
\text { space } \\
(\% \mathrm{v} / \mathrm{v})\end{array}$ & $\begin{array}{c}\text { Air-filled } \\
\text { pore space } \\
(\% \mathrm{v} / \mathrm{v})\end{array}$ & $\begin{array}{c}\text { Water-holding } \\
\text { capacity } \\
(\% \mathrm{v} / \mathrm{v})\end{array}$ \\
\hline$\overline{100 \% \text { peat: } 0 \% \mathrm{PBH}}$ & & 0.08 & 0.36 & 70.5 & 12.6 & 57.9 \\
\hline $90 \%$ peat: $10 \% \mathrm{PBH}$ & & 0.09 & 0.41 & 72.5 & 15.3 & 57.2 \\
\hline $80 \%$ peat: $20 \% \mathrm{PBH}$ & & 0.09 & 0.44 & 74.4 & 21.8 & 52.7 \\
\hline $70 \%$ peat: $30 \% \mathrm{PBH}$ & & 0.09 & 0.46 & 74.9 & 25.9 & 49.1 \\
\hline $60 \%$ peat: $40 \% \mathrm{PBH}$ & & 0.11 & 0.52 & 73.5 & 30.7 & 42.8 \\
\hline $100 \%$ RH3:0\% PBH & & 0.21 & 0.72 & 65.6 & 13.0 & 52.6 \\
\hline $90 \%$ RH3:10\% PBH & & 0.20 & 0.73 & 67.0 & 15.9 & 51.1 \\
\hline $80 \%$ RH3:20\% PBH & & 0.19 & 0.66 & 65.2 & 16.4 & 48.8 \\
\hline $70 \%$ RH3:30\% PBH & & 0.19 & 0.65 & 65.5 & 18.6 & 46.9 \\
\hline $60 \%$ RH3:40\% PBH & & 0.16 & 0.60 & 67.5 & 20.8 & 46.6 \\
\hline Significance & $\mathrm{df}$ & & & & & \\
\hline Peat versus RH3 & 1 & $* * *$ & $* * *$ & $* * *$ & *** & *** \\
\hline $100 \%$ peat versus $100 \%$ RH3 & 1 & *** & *** & ** & NS & ** \\
\hline $90 \%$ peat versus $90 \%$ RH3 & 1 & $* * *$ & $* * *$ & $* * *$ & NS & $* * *$ \\
\hline $80 \%$ peat versus $80 \%$ RH3 & 1 & $* * *$ & $* * *$ & $* * *$ & ** & * \\
\hline $70 \%$ peat versus $70 \%$ RH3 & 1 & $* * *$ & $* * *$ & $* * *$ & $* * * *$ & NS \\
\hline $60 \%$ peat versus $60 \%$ RH3 & 1 & *** & * & *** & $* * *$ & * \\
\hline
\end{tabular}

${ }^{\mathrm{z}}$ Substrate composition indicates percentage sphagnum peat (peat), ground parboiled fresh rice hulls (RH3), and PBH.

Ns, *, **, ***Nonsignificant or significant at $P>\mathrm{F}=0.05,0.01$, or 0.001 , respectively. containing $20 \%$ or more $\mathrm{PBH}$. $\mathrm{PBH}$ has been reported to create large pore spaces as a result of cross-bridging of the elongated nature of the PBH particle (Evans and Gachukia, 2007). As the amount of $\mathrm{PBH}$ increased, the proportion of large pores increased. An abundance of large pores in which fine RH3 particles could settle could therefore reduce the proportion of large pores and thus reduce the AFP. The larger peat particles would have been less able to settle and fill in these large pores. In most of the substrates, peat-based substrates had higher WHC than equivalent RH3-based substrates. However, when perlite or bark was used as the aggregate, WHC of all substrates were within acceptable levels. When $\mathrm{PBH}$ was used as the aggregate, WHC of peat-based substrates containing up to $20 \%$ PBH were within acceptable ranges (Arnold Bik, 1983; Boertje, 1984). These results are consistent with previous research (Evans and Gachukia, 2007) on PBH in which it was reported that incorporating high proportions of PBH greatly reduced the WHC of substrates.

The physical properties of $100 \%$ RH3 reported for this experiment were slightly different from those reported in the previous experiment. These differences are likely the result of the different methods used to determine the physical properties. In the first experiment, the porometer method was used to determine physical properties, whereas in subsequent experiments, the tube method was used. Niedziela and Nelson (1992) reported differences in physical properties between various methods and the tube method, although the differences were reported to be small. Regardless of the method used to determine physical properties, they were within recommended ranges for greenhouse substrates. Furthermore, although there were differences in physical properties between peat- and RH3-based substrates with the incorporation of different amounts of common aggregates, physical properties of all RH3based substrates were within commonly recommended ranges. Therefore, based on these physical property results, RH3 could be used as a substrate component in lieu of peat and combined with different common aggregates to achieve a substrate with acceptable physical properties.

Physical properties of root substrates containing ground parboiled fresh rice hulls as a partial replacement of peat. When perlite was used as the substrate aggregate, substrates containing $10 \% \mathrm{RH} 3$ had a similar $\mathrm{BD}$ as the substrate containing $0 \% \mathrm{RH} 3$ (Table 6). However, when the concentration of RH3 was $20 \%$ or higher, the substrates had a higher $\mathrm{BD}$ than the peat control. Particle density was not significantly different among the substrates. Total pore space was similar for all perlite-amended substrates except for the $40 \%$ RH3 substrate, which had a lower TPS than the peat control. All substrates that contained RH3 had lower AFP than the peat control. Substrates containing $10 \%$ to $30 \%$ RH3 had higher WHC than the peat control, but substrates containing 40\% RH3 had a similar WHC as the peat control. 
When bark was used as the substrate aggregate, substrates containing $10 \%, 20 \%$, and $40 \%$ RH3 had a similar BD as the substrate containing $0 \%$ RH3 (Table 7). However, substrates containing 30\% RH3 had a higher BD than the peat control. Particle density was not significantly different among the substrates. Total pore space was similar for all bark-amended substrates except for the $30 \%$ RH3 substrate, which had a lower TPS than the peat control. The substrate containing $10 \% \mathrm{RH} 3$ had a similar AFP as the peat control, but all other RH3containing substrates had lower AFP than the peat control. The substrate containing 10\% RH3 had a higher WHC than the peat control, but all other RH3-containing substrates had a similar WHC as the peat control.

Table 6. Physical properties of sphagnum peat-based substrates amended with $20 \%$ perlite and the remaining volume being ground parboiled fresh rice hulls

\begin{tabular}{|c|c|c|c|c|c|c|c|c|}
\hline \multicolumn{4}{|c|}{ Substrate composition $(\% \mathrm{v} / \mathrm{v})^{\mathrm{z}}$} & \multirow{2}{*}{$\begin{array}{c}\text { Bulk } \\
\text { density } \\
\left(\mathrm{g} \cdot \mathrm{cm}^{-3}\right)\end{array}$} & \multirow{2}{*}{$\begin{array}{c}\text { Avg particle } \\
\text { density } \\
\left(\mathrm{g} \cdot \mathrm{cm}^{-3}\right)\end{array}$} & \multirow{2}{*}{$\begin{array}{c}\text { Total pore } \\
\text { space } \\
(\% \mathrm{v} / \mathrm{v})\end{array}$} & \multirow{2}{*}{$\begin{array}{c}\text { Air-filled } \\
\text { pore space } \\
(\% \mathrm{v} / \mathrm{v})\end{array}$} & \multirow{2}{*}{$\begin{array}{c}\text { Water-holding } \\
\text { capacity } \\
(\% \mathrm{v} / \mathrm{v})\end{array}$} \\
\hline Peat & RH3 & Perlite & & & & & & \\
\hline$\overline{80}$ & 0 & 20 & & 0.10 & 0.72 & 79.1 & 21.5 & 57.6 \\
\hline 70 & 10 & 20 & & 0.11 & 0.73 & 77.2 & 14.5 & 62.7 \\
\hline 60 & 20 & 20 & & 0.14 & 0.90 & 78.2 & 14.0 & 64.2 \\
\hline 50 & 30 & 20 & & 0.15 & 0.85 & 76.3 & 12.5 & 63.8 \\
\hline 40 & 40 & 20 & & 0.12 & 0.70 & 72.5 & 12.5 & 60.0 \\
\hline \multicolumn{3}{|c|}{ Significance } & df & & & & & \\
\hline \multicolumn{3}{|c|}{ Substrate } & 4 & $* * *$ & NS & NS & $* *$ & ** \\
\hline \multicolumn{3}{|c|}{$0 \%$ RH3 versus $10 \%$ RH3 } & 1 & NS & NS & NS & $* *$ & ** \\
\hline \multicolumn{3}{|c|}{$0 \%$ RH3 versus $20 \%$ RH3 } & 1 & $* * *$ & NS & NS & $* *$ & $* * *$ \\
\hline \multicolumn{3}{|c|}{$0 \%$ RH3 versus $30 \%$ RH3 } & 1 & $* * *$ & NS & NS & $* * *$ & ** \\
\hline \multicolumn{3}{|c|}{$0 \%$ RH3 versus $40 \%$ RH3 } & 1 & $*$ & NS & $*$ & $* * *$ & NS \\
\hline
\end{tabular}

zPeat was a sphagnum peat. RH3 was a commercially available parboiled rice hull product ground using a hammer mill, passed through a $1.18-\mathrm{mm}$ screen, and collected on a $0.18-\mathrm{mm}$ screen (Riceland Foods, Stuttgart, AR).

NS, $* * *, * * *$ Nonsignificant or significant at $P>\mathrm{F}=0.05,0.01$, or 0.001 , respectively.

Table 7. Physical properties of sphagnum peat-based substrates amended with $20 \% 1 \mathrm{~cm}$ aged pine bark and the remaining volume being ground parboiled fresh rice hulls.

\begin{tabular}{|c|c|c|c|c|c|c|c|c|}
\hline \multicolumn{3}{|c|}{ Substrate composition $(\% \mathrm{v} / \mathrm{v})^{\mathrm{z}}$} & & \multirow{2}{*}{$\begin{array}{c}\text { Bulk } \\
\text { density } \\
\left(\mathrm{g} \cdot \mathrm{cm}^{-3}\right)\end{array}$} & \multirow{2}{*}{$\begin{array}{c}\text { Avg particle } \\
\text { density } \\
\left(\mathrm{g} \cdot \mathrm{cm}^{-3}\right)\end{array}$} & \multirow{2}{*}{$\begin{array}{c}\text { Total pore } \\
\text { space } \\
(\% \mathrm{v} / \mathrm{v})\end{array}$} & \multirow{2}{*}{$\begin{array}{c}\text { Air-filled } \\
\text { pore space } \\
(\% \mathrm{~V} / \mathrm{v})\end{array}$} & \multirow{2}{*}{$\begin{array}{c}\text { Water-holding } \\
\text { capacity } \\
(\% \mathrm{v} / \mathrm{v})\end{array}$} \\
\hline Peat & RH3 & Bark & & & & & & \\
\hline$\overline{80}$ & 0 & 20 & & 0.12 & 0.73 & 79.0 & 21.2 & 57.8 \\
\hline 70 & 10 & 20 & & 0.12 & 0.88 & 80.1 & 18.4 & 61.7 \\
\hline 60 & 20 & 20 & & 0.14 & 0.83 & 76.2 & 16.5 & 59.7 \\
\hline 50 & 30 & 20 & & 0.15 & 0.67 & 73.4 & 15.4 & 58.0 \\
\hline 40 & 40 & 20 & & 0.11 & 0.79 & 74.7 & 17.7 & 57.0 \\
\hline \multicolumn{3}{|c|}{ Significance } & df & & & & & \\
\hline \multicolumn{3}{|c|}{ Substrate } & 4 & NS & NS & $*$ & * & $*$ \\
\hline \multicolumn{3}{|c|}{$0 \%$ RH 3 versus $10 \%$ RH3 } & 1 & NS & NS & NS & NS & * \\
\hline \multicolumn{3}{|c|}{$0 \%$ RH 3 versus $20 \%$ RH3 } & 1 & NS & NS & NS & * & NS \\
\hline \multicolumn{3}{|c|}{$0 \%$ RH3 versus $30 \%$ RH3 } & 1 & $*$ & NS & $*$ & $* *$ & NS \\
\hline \multicolumn{3}{|c|}{$0 \%$ RH 3 versus $40 \%$ RH3 } & 1 & NS & NS & NS & * & NS \\
\hline
\end{tabular}

zPeat was a sphagnum peat. RH3 was a commercially available parboiled rice hull product ground using a hammer mill, passed through a $1.18-\mathrm{mm}$ screen, and collected on a $0.18-\mathrm{mm}$ screen (Riceland Foods, Stuttgart, AR).

NS, $* * *, * * *$ Nonsignificant or significant at $P>\mathrm{F}=0.05,0.01$, or 0.001 , respectively.

Table 8 . Physical properties of sphagnum peat-based substrates amended with $20 \% \mathrm{PBH}$ and the remaining volume being ground parboiled fresh rice hulls.

\begin{tabular}{|c|c|c|c|c|c|c|c|c|}
\hline \multicolumn{4}{|c|}{ Substrate composition $(\% \mathrm{v} / \mathrm{v})^{\mathrm{z}}$} & \multirow{2}{*}{$\begin{array}{l}\text { Bulk } \\
\text { density } \\
\left(\mathrm{g} \cdot \mathrm{cm}^{-3}\right)\end{array}$} & \multirow{2}{*}{$\begin{array}{c}\text { Avg particle } \\
\text { density } \\
\left(\mathrm{g} \cdot \mathrm{cm}^{-3}\right)\end{array}$} & \multirow{2}{*}{$\begin{array}{c}\text { Total pore } \\
\text { space } \\
(\% \mathrm{v} / \mathrm{v})\end{array}$} & \multirow{2}{*}{$\begin{array}{c}\text { Air-filled } \\
\text { pore } \\
\text { space }(\% \mathrm{v} / \mathrm{v})\end{array}$} & \multirow{2}{*}{$\begin{array}{c}\text { Water-holding } \\
\text { capacity } \\
(\% \mathrm{v} / \mathrm{v})\end{array}$} \\
\hline Peat & RH3 & $\mathrm{PBH}$ & & & & & & \\
\hline$\overline{80}$ & 0 & 20 & & 0.09 & 0.68 & 82.0 & 24.5 & 57.5 \\
\hline 70 & 10 & 20 & & 0.11 & 0.78 & 80.9 & 23.9 & 57.0 \\
\hline 60 & 20 & 20 & & 0.11 & 0.62 & 76.2 & 24.9 & 51.3 \\
\hline 50 & 30 & 20 & & 0.14 & 0.85 & 77.6 & 19.9 & 57.7 \\
\hline 40 & 40 & 20 & & 0.16 & 0.89 & 76.4 & 16.9 & 59.5 \\
\hline \multicolumn{3}{|c|}{ Significance } & df & & & & & \\
\hline \multicolumn{3}{|c|}{ Substrate } & 4 & $* * *$ & NS & $* *$ & $* * *$ & $* * *$ \\
\hline \multicolumn{3}{|c|}{$0 \%$ RH3 versus $10 \%$ RH3 } & 1 & $* *$ & $* *$ & NS & NS & NS \\
\hline \multicolumn{3}{|c|}{$0 \%$ RH3 versus $20 \%$ RH3 } & 1 & $* * *$ & NS & $* *$ & NS & $* * *$ \\
\hline \multicolumn{3}{|c|}{$0 \%$ RH3 versus $30 \%$ RH3 } & 1 & $* * *$ & $* * *$ & $*$ & $* * *$ & NS \\
\hline \multicolumn{3}{|c|}{$0 \%$ RH3 versus $40 \%$ RH3 } & 1 & $* * *$ & $* * *$ & $* *$ & $* * *$ & NS \\
\hline
\end{tabular}

zPeat was a sphagnum peat. RH3 was a commercially available parboiled rice hull product ground using a hammer mill, passed through a $1.18-\mathrm{mm}$ screen, and collected on a $0.18-\mathrm{mm}$ screen (Riceland Foods, Stuttgart, AR).

Ns, $* * *, * * *$ Nonsignificant or significant at $P>\mathrm{F}=0.05,0.01$, or 0.001 , respectively.

When $\mathrm{PBH}$ was used as the aggregate, all RH3-containing substrates had a higher BD than the peat control (Table 8). However, the average PD was higher for the $10 \%, 30 \%$, and $40 \% \mathrm{RH} 3$-containing substrates than the peat control. The $10 \%$ RH3 substrate had a similar TPS as the peat control, but all other RH3containing substrates had lower TPS than the peat control. The $10 \%$ and $20 \%$ RH3 substrates had a similar AFP as the peat control, but all other RH3-containing substrates had lower AFP than the peat control. Substrates containing $10 \%, 30 \%$, and $40 \%$ RH3 had similar WHC as the peat control, but the substrate containing 20\% RH3 had lower WHC than the peat control.

Incorporation of RH3 as a partial replacement of peat resulted in less predictable results in physical properties than when RH3 was used as a complete peat replacement. Several factors had a role in the differences in physical properties. With the mixing of three types of particles, the unique ways in which the combinations settled and packed was less predictable. Because less RH3 was added to these substrates, the effect of RH3 on the substrate was reduced as compared with substrates in which $\mathrm{RH} 3$ replaced $100 \%$ of the peat. Finally, as the number of components increased, the potential for errors from mixing and blending of the substrates could have introduced increased variability. Regardless of the amount or type of aggregate, all substrates had physical properties within acceptable ranges for greenhouse crops (Bunt, 1988). Based on physical properties, substrates could be formulated with RH3 as a complete or as a partial alternative to peat with various aggregates to produce substrates with suitable physical properties for greenhouse crop production.

\section{Literature Cited}

Arnold Bik, R. 1983. Substrates in floriculture. Proc. XXI Intl. Hort Congr. 2:811-822.

Barkham, J.P. 1993. For peat's sake: Conservation or exploitation. Biodivers. Conserv. 11:1877-1887.

Beeson, R.C. 1996. Composted yard waste as a component of container substrates. J. Environ. Hort. 14:115-121.

Boertje, G.A. 1984. Physical laboratory analyses of potting composts. Acta Hort. 150:47-50.

Buamscha, M.G., J.E. Altland, D.M. Sullivan, D.A. Horneck, and J. Cassidy. 2007. Chemical and physical properties of douglas fir bark relevant to the production of container plants. HortScience 42:1281-1286.

Buckland, P.C. 1993. Peatland archeology: A conservation resource on the edge of extinction. Biodivers. Conserv. 2:513-527.

Bunt, A.C. 1988. Media and mixes for container grown plants. Unwin Hyman, Ltd., London, UK.

Byrne, P.J. and B. Carty. 1989. Developments in the measurement of air filled porosity of peat substrates. Acta Hort. 238:37-44.

Carter, M. 1993. Soil sampling and methods of analysis. CRC Press LLC, Boca Raton, FL.

Chong, C. and R.A. Cline. 1993. Response of four ornamental shrubs to container substrate amended with two sources of raw paper mill sludge. HortScience 29:807-809.

De Boodt, M. and O. Verdonck. 1972. The physical properties of the substrates in horticulture. Acta Hort. 26:37-44. 
Evans, M.R. 2004. Processed poultry feather fiber as an alternative to peat in greenhouse crops substrates. HortTechnology 14:176-179.

Evans, M.R. and M. Gachukia. 2004. Fresh parboiled rice hulls serve as an alternative to perlite in greenhouse crop substrates. HortScience 39:232-235.

Evans, M.R. and M. Gachukia. 2007. Physical properties of sphagnum peat-based root substrates amended with perlite or parboiled fresh rice hulls. Hort Technology 17:312-315.

Evans, M.R., S. Konduru, and R. Stamps. 1996. Source variation in physical and chemical properties of coconut coir dust. HortScience 31:965-967.

Evans, M.R. and R.H. Stamps. 1996. Growth of bedding plants in Sphagnum peat and coir dustbased substrates. J. Environ. Hort. 14:187190.

Fonteno, W.C. and T.E. Bilderback. 1993. Impact of hydrogel on physical properties of coarsestructured horticultural substrates. J. Amer. Soc. Hort. Sci. 118:217-222.

Hanan, J.J. 1998. Greenhouses: Advanced technology for protected horticulture. CRC Press, Boca Raton, FL.
Ingram, R.E., R.W. Henley, and T.H. Yeager 1993. Growth media for container plants. Florida Coop. Ext. Serv. Univ. of Florida. Bul. 24.

Jackson, B.E., R.D. Wright, and M.C. Barnes. 2008. Pine tree substrate, nitrogen rate, particle size and peat amendment affect poinsettia growth and substrate physical properties. HortScience 43:2155-2161.

Jenkins, J.R. and W.M. Jarrell. 1989. Predicting physical and chemical properties of container mixtures. HortScience 24:292-295.

Juliano, B., C. Maningat, and C. Pascual. 1987. Properties of fraction of rice hull. Phytochem. 26:3261-3263.

Kamath, S. and A. Proctor. 1998. Silica gel from rice hull ash: Preparation and characterization. Cereal Chem. 75:484-487.

Laiche, A.J., Jr and V.E. Nash. 1990. Evaluation of composted rice hulls and a lightweight clay aggregate as components of container-plant growth media. J. Environ. Hort. 8:14-18.

Nelson, P.V. 2003. Greenhouse operation and management. 6th Ed. Prentice Hall, Upper Saddle River, NJ.

Niedziela C.E., Jr and P.V. Nelson. 1992. A rapid method for determining physical properties of undisturbed substrate. HortScience 27:12791280.

Raviv, M. and J.H. Lieth. 2008. Soilless culture: Theory and practice. Elsevier, Maryland Heights, MO.

Robertson, R.A. 1993. Peat, horticulture and environment. Biodivers. Conserv. 2:541-547.

Sambo, P., F. Sannazzaro, and M.R. Evans. 2008 Physical properties of ground fresh rice hulls and sphagnum peat used for greenhouse root substrates. HortTechnology 18:384-388.

Tyler, H.H., S.L. Stuart, T.E. Bilderback, and K.B. Perry. 1993. Composted turkey litter: II. Effect on plant growth. J. Environ. Hort. 11:137-141.

Wang, Y.T. 1991. Evaluation of media consisting of a cotton waste for the production of tropical foliage species. J. Environ. Hort. 9:112-115.

Wang, Y.T. 1994. Using ground kenaf stem core as a major component of container media. J. Amer. Soc. Hort. Sci. 19:931-935.

Yeager, T., T. Bilderback, D. Fare, C. Gilliam, C. Lea-Cox, A. Niemiera, J. Ruter, K. Tilt, S. Warren, T. Whitwell, and R. Wright. 2007. Best management practices: Guide for producing nursery crops. 2nd Ed. Southern Nursery Assn., Atlanta, GA. 